\title{
Risk of HPV-related extra-cervical cancers in women treated for cervical intraepithelial neoplasia
}

\author{
Mario Preti ${ }^{1}$, Stefano Rosso ${ }^{2}$, Leonardo Micheletti ${ }^{1}$, Carola Libero ${ }^{1}$, Irene Sobrato ${ }^{2}$, Livia Giordano ${ }^{3}$, Paola Busso ${ }^{2}$, \\ Niccolò Gallio ${ }^{1 *}$ iD, Stefano Cosma ${ }^{1}$, Federica Bevilacqua ${ }^{1}$ and Chiara Benedetto ${ }^{1}$
}

\begin{abstract}
Background: The aim was to estimate the risk of subsequent extra-cervical Human Papillomavirus (HPV) related cancer in patients surgically treated for high grade cervical intraepithelial neoplasia (CIN 2-3). This is the first study in Italy investigating the occurrence of extra-cervical tumors in this cohort of patients.

Methods: 3184 patients surgically treated for CIN2-3 since 1992 at the Department of Surgical Sciences of University of Torino were considered. The risk of HPV-related cancer was calculated as Standardized Incidence Ratio (SIR), using as expected values tumour age specific incidence of resident population.

Results: 173 second primary cancer (SCPs) were identified. SIR to develop cancer after treatment for CIN2-3 was 2.2 (CI 95\% 1.89-2.50). Among these occurrences, 10 are in HPV related sites: 1 anus (SIR $=1.8 ; 0.04-10.0), 3$ vagina $(\mathrm{SIR}=12.4 ; 2.56-36.3), 1$ vulva $(\mathrm{SIR}=1.7 ;$ 0.04-9.59), 5 oropharynx $(\mathrm{SIR}=8.5 ; 2.76-19.8)$.

Significant risk has been also recorded for pulmonary $(S I R=3.1 ; 0.70-5.27)$ and bladder $(S I R=4.05 ; 1.10-10.56)$, with smoking as possible cofactor. We also found increased risk for breast (SIR $=2.4 ; 2.07-2.84$ ) and ovarian cancers $(S I R=2.1 ; 1.13-3.49)$, probably due to an higher adherence to spontaneous and programmed screening programs.

Conclusions: Our study supports the hypothesis of an increased risk of HPV-related tumours for CIN treated patients, mostly for CIN3. It is conceivable the need of early diagnosis for these cancers in this higher-risk populations.
\end{abstract}

Keywords: HPV-related cancers, Anogenital area, Anal cancer, Vaginal cancer, Vulvar cancer, Multiple subsequent cancers

\section{Background}

High-risk human papillomaviruses (hrHPV) are estimated to cause $5.2 \%$ of all cancers worldwide, with HPV16 alone responsible for approximately 70\% of cervical cancer, that is the first most common HPV-related cancer in women [1]. HPV are also detectable in 15$48 \%$ of vulvar, $68-86 \%$ of vaginal, $85-91 \%$ of anal,19-

\footnotetext{
* Correspondence: niccolo.gallio@edu.unito.it

'Department of Surgical Sciences University of Torino, Via Ventimiglia 3, 10126 Torino, Italy

Full list of author information is available at the end of the article
}

$25 \%$ of oropharyngeal, $3-5 \%$ of oral cavity, $2-5 \%$ of larynx cancers [2-5].

Precancerous lesions precede these cancers, and cervical intraepithelial neoplasia (CIN) is the most studied and treated. Despite CIN treatment has a high impact in reducing cancer risk (from 95 to 99\%), treated women are still considered at higher risk of cervical malignancies compared to the general population and at risk of HPVrelated malignancies in other body sites [6, 7]. Many studies demonstrated that women with history of diagnosis and treatment for high-grade CIN are at increased risk for

(c) The Author(s). 2020 Open Access This article is licensed under a Creative Commons Attribution 4.0 International License, which permits use, sharing, adaptation, distribution and reproduction in any medium or format, as long as you give appropriate credit to the original author(s) and the source, provide a link to the Creative Commons licence, and indicate if changes were made. The images or other third party material in this article are included in the article's Creative Commons licence, unless indicated otherwise in a credit line to the material. If material is not included in the article's Creative Commons licence and your intended use is not permitted by statutory regulation or exceeds the permitted use, you will need to obtain permission directly from the copyright holder. To view a copy of this licence, visit http://creativecommons.org/licenses/by/4.0/ The Creative Commons Public Domain Dedication waiver (http://creativecommons.org/publicdomain/zero/1.0/) applies to the data made available in this article, unless otherwise stated in a credit line to the data. 
HPV subsequent primary cancers (SPCs) [6-16]. An HPV-SPC is defined as a metachronous invasive primary solid tumour, which develops at least 2 months after the diagnosis of a primary HPV-related tumour [17].

Viral, host, and behavioral variables may increase the risk of cancer development allowing persistence of HPV infection.

The viral genotype present influences risk and HPV 16 infection has the highest risk of viral persistence and subsequent precancer/cancer development [15].

Host immunoresponse influence the effectiveness of viral clearance: primary immunodeficiency disorders but also polymorphisms in genes such as TLRs (Toll-Like receptors) and NF-kB networks are associated with higher risk of lesions [18]. Also secondary immunodeficiencies either infection-related (HIV) or iatrogenic (chemotherapy or biological drugs) elevate the risk of HPV related malignancies [4].

Sexual behaviors such as number of partners, young age at first intercourse, frequency and type of sexual practices and partners' sexual histories are risk factors for developing HPV related cancers [19]. Smoking is still debate as risk factors, but it seems that it can play a role in transition from HPV infection to precancer [20].

The aim of this study was to estimate the risk of developing SPCs and the site of occurrence in a cohort of women resident in Piedmont (North-West Italy Region) previously treated for high-grade $\mathrm{CIN}$, distinguishing between HPV-related and non-HPV-related sites.

This is, at our knowledge, the first study in Italian population with the aim to provide accurate risk estimates of occurrence of a prior CIN represents an increased risk for HPV-related SPCs.

\section{Methods}

Individual clinical information on all patients surgically treated with large loop excision of transformation zone (LLETZ) procedure at the Department of Surgical Sciences of the University of Torino, St. Anna Hospital for highgrade CIN from 1992 to 2016 were recruited in the cohort (6649 patients). Women treated after 2014 were excluded in order to have at least 5 years of follow-up for each patient, reducing the cohort at 5595 women. This database was linked with the Piedmont Cancer Registry (Registro Tumori Piemonte: RTP) to retrieve information on subsequent neoplasm (excluding non-melanoma skin cancers). RTP registered cancers among residents only in the Municipality of Turin between 1985 and 2007, the residents in the larger Turin Metropolitan Area since 2008, and finally in the whole region since 2013. Patients in the cohort were considered only if resident in the corresponding area for the period above mentioned, otherwise they were discarded from the cohort. The study cohort was thus reduced to 3184 patients.
Expected cases by type of cancer were calculated in the reduced cohort applying corresponding specific rates [http://ci5.iarc.fr; www.cpo.it] by age class (five-year groups: 0-85+), period (Turin Municipality: years 1992-1997, 1998-2002, 2003-2007, 2008-2012, 2013-2014; Metropolitan Area: years 2008-2012, 2013-2014; Piedmont Region: years 2013-2014) and cancer site. Person-years in the cohort were calculated with month approximation at followup date and time of surgery (as starting observation time).

All tumours were classified by anatomical site using the International Classification of Cancer Pathologies, 3rd edition ICD-O 3. Risk of SPCs was then calculated dividing number of observed and expected cases as Standardized Incidence Ratio (SIR). Confidence interval of SIR were derived using Haenszel's exact method [21].

\section{Results}

The study cohort of 3184 patients resident in Piedmont during the period and in the area of RTP registration was observed for a total of 20,022 person-years up to the end of 2014.

In this period, a total of 173 neoplasms were registered in these women (Table 1) with an overall SIR of 2.2 (95\% exact CI: 1.89-2.50). In particular, HPV-related cancer site showed an important and statistically significant risk increase in patients surgically treated for CIN2-3. Overall oropharynx cancers (5 cases) exhibited a SIR of 8.5 (95\% exact CI: 2.76-19.8). Tongue cancers were the most frequent among them, 4 occurrences and SIR of 14.1 (95\% exact CI: 3.84-36.2).

We had a SIR of 1.8 (95\% exact CI: 0.04-10.00) in anal area, 1,7 (95\% exact CI: 0.04-9.59) and 12.4 (95\% exact CI: 2.56-36.3) in vulvar and vaginal localization respectively.

Summing up all these HPV related sites we had 10 cases with a significant SIR of 5.1 (95\% exact CI: 2.449.38). For each positive case of SPC, we checked, consulting the database created, whether patients were treated for CIN 2 or CIN 3: an higher risk of developing SPCs was found in CIN 3 treated patients, SIR of 6.08 (95\% exact CI: 2.44-12.53), compared to CIN2, SIR of 1.43 (95\% exact CI: 0.57-2.94). (Table 2).

An excess risk of other cancers not strictly related to HPV infection was also observed. In particular, 15 lung cancers, SIR 3.1 (95\% exact CI: 0.70-5.27); 3 bladder cancers, SIR 4.05 (95\% exact CI: 1.10-10.56). 62 subsequent breast cancers and 7 ovarian cancers ((SIR respectively 2.4 (95\% exact CI: $2.07-2.84)$ and 2.1 (95\% exact CI: 1.13-3.49)).

\section{Discussion}

The study was performed to estimate the risk of SPCs in extra-cervical sites in women surgically treated for CIN 2 and CIN 3. Recently, similar studies have been published, with slightly different criteria of inclusion $[6-14,16,22-$ 24]. Sexually transmitted HPV infection is common, but 
Table 1 Observed subsequent cancers in a cohort of patients treated with LLETZ for CIN2-3 [excluding non-melanoma skin cancers]

\begin{tabular}{|c|c|c|}
\hline Cancer Site & ICDO-3 codes & Observed SPCs \\
\hline Oropharynx & $\mathrm{C} 01-\mathrm{C} 10$ & 5 \\
\hline Oesophagus & $\mathrm{C} 15$ & 1 \\
\hline Colon-rectum & C18-20 & 20 \\
\hline Anus & $\mathrm{C} 21$ & 1 \\
\hline Liver & $\mathrm{C} 22$ & 1 \\
\hline Gallbladder & C24 & 2 \\
\hline Pancreas & $\mathrm{C} 25$ & 1 \\
\hline Lung & C33-C34 & 15 \\
\hline Melanoma & C44 & 11 \\
\hline Soft Tissues & C49 & 1 \\
\hline Breast & C50 & 62 \\
\hline Vulva & C51 & 1 \\
\hline Vagina & C52 & 3 \\
\hline Corpus Uteri & C54 & 9 \\
\hline Ovary & C56 & 7 \\
\hline Kidney & C64 & 2 \\
\hline Bladder & $\mathrm{C} 67$ & 3 \\
\hline SNC & $\mathrm{C} 71$ & 1 \\
\hline Thyroid & $\mathrm{C} 73$ & 6 \\
\hline Parathyroid & $\mathrm{C} 75$ & 1 \\
\hline Myeloma & C42 & 5 \\
\hline Lymphomas & $\mathrm{C} 77$ & 9 \\
\hline Leukaemias & C42 & 2 \\
\hline Others & & 4 \\
\hline Total & & 173 \\
\hline
\end{tabular}

\section{Legenda:}

ICDO-3 International Classification of Diseases for Oncology 3rd Edition LLETZ Large Loop Excision of the Transformation Zone

SPCS Second Primary Cancers

Table 2 HPV-related cancers in CIN 2-3 LLETZ treated patients. Standardized Incidence Rates according to Haenszel's formula

\begin{tabular}{llllll}
\hline Cancer Site & $\begin{array}{l}\text { ICDO-3 } \\
\text { codes }\end{array}$ & $\begin{array}{l}\text { Observed } \\
\text { SPCs }\end{array}$ & $\begin{array}{l}\text { Expected } \\
\text { SPCs }\end{array}$ & SIR & $\mathbf{9 5 \% ~ C I}$ \\
\hline Oropharynx & C01-C10 & 5 & 0.59 & 8.5 & $2.76-19.8$ \\
Anus & C21 & 1 & 0.55 & 1.8 & $0.04-10.0$ \\
Vulva & C51 & 1 & 0.58 & 1.7 & $0.04-9.59$ \\
Vagina & C52 & 3 & 0.24 & 12.4 & $2.56-36.3$ \\
Total & & $\mathbf{1 0}$ & $\mathbf{1 . 9 6}$ & $\mathbf{5 . 1}$ & $\mathbf{2 . 4 4 - 9 . 3 8}$
\end{tabular}

Legenda:

ICDO-3 International Classification of Diseases for Oncology 3rd Edition LLETZ Large Loop Excision of the Transformation Zone

SPCS Second Primary Cancers

SIR Standardized Incidence Ratio

Cl Confidence Interval usually transient: $80 \%$ of infected women spontaneously eliminate HPV within 2 years of acquisition [3].

The presence of high-grade CIN is a good proxy for persistent high-risk HPV infection. The common viral HPV aetiology for a subset of extra cervical tumours factor explains why women with history of CIN2 or CIN3 have a significantly higher risk of anal, vulvar, vaginal, and oral cancer [16, 25].

Women whose inadequate immune response failed to clear HPV infection and allowed viral persistence and CIN development are at higher risk for HPV persistence after CIN treatment and subsequent related lesions [24].

An immunological failure could be present, together with other specific risks, in other body sites, consequently increasing the risk of lesions elsewhere [4, 17]. The common risk factors as HPV 16 persistent infection and other behavioural factors as smoking and sexual practices could also increase risk for SPCs development, in the presence of a persistent HPV infection [3].

\section{Anogenital region}

In (Table 3) we compare our study with the literature data. All studies use SIR or Relative Risk (RR) to estimate the correlation between primary cervical lesions and SPCs.

Table 3 Anogenital SPCs in CIN 2-3 LLETZ treated women. A comparison between literature and our study data

\begin{tabular}{|c|c|c|c|c|c|c|}
\hline Author & Year & First lesion & Value & Vulva & Vagina & Anus \\
\hline Evans [26] & 2003 & CIN 3 & SIR & 4.4 & 18.5 & 5.9 \\
\hline Kalliala [6] & 2005 & CIN 1-3 & SIR & 4.1 & 12 & 5.7 \\
\hline Edgren [9] & 2007 & CIN 3 & IRR & 2.2 & 6.7 & 4.7 \\
\hline Strander [22] & 2007 & CIN 3 & RR & & 6.8 & \\
\hline \multirow[t]{2}{*}{ Saleem [12] } & 2007 & CIN3 & $\mathrm{SIR}$ & - & - & 16.4 \\
\hline & & SCC & $\mathrm{SIR}$ & - & - & 6.2 \\
\hline Tatti [27] & 2012 & CIN 2-3 & OR & - & - & 1.91 \\
\hline \multirow[t]{3}{*}{ Gaudet [10] } & 2014 & CIN 2 & SIR & 1.47 & 3.61 & 0.89 \\
\hline & & CIN 3 & SIR & 3.79 & 8.53 & 2.28 \\
\hline & & CIN2-3 & $\mathrm{SIR}$ & 2.9 & 6.65 & 1.75 \\
\hline \multirow[t]{2}{*}{ Sand [11] } & 2016 & CIN 2 & $\mathrm{RR}$ & 2.5 & 8.1 & 2.9 \\
\hline & & CIN 3 & RR & 4 & 17.1 & 4.2 \\
\hline Ebisch [8] & 2017 & CIN 3 & IRR & 4.97 & 86.08 & 3.85 \\
\hline Suk [23] & 2018 & SCC & $\mathrm{SIR}$ & 3.8 & 17.3 & 2.3 \\
\hline $\begin{array}{l}\text { Acevedo } \\
\text { Fontánez [14] }\end{array}$ & 2018 & SCC & SIR & - & - & 51.6 \\
\hline Wang [16] & 2020 & SCC & $\mathrm{SIR}$ & 2.29 & 1.85 & 1.41 \\
\hline Our study & & CIN 2-3 & $\mathrm{SIR}$ & 1.7 & 12.4 & 1.8 \\
\hline \multicolumn{6}{|c|}{$\begin{array}{l}\text { IRR Incidence Rate Ratio } \\
\text { LLETZ Large Loop Excision of the Transformation Zone } \\
\text { RR Relative Risk }\end{array}$} & \\
\hline
\end{tabular}


Surgical removal (LLETZ) of CIN does not mean removal of HPV infection and HPV DNA can be present in surrounding, clinical normal tissues and this viral persistence can rise the subsequent precancer/cancer risk [7].

The correlation between anogenital tumour or pretumour lesions and HPV infection has been well described [18]. There is general consensus in stating that patients treated for high grade CIN or cervical cancer are at increased risk of invasive neoplasia and our study confirms this trend $[5-14,16]$.

In our study all SPCs found in anal, vulvar and vaginal sites occurred in women with previous history of CIN 3 . No case of CIN 2 determined SPCs in the anogenital area. This could be explained by the more reproducible diagnosis of CIN 3 respect to CIN 2 and with the longer HPV persistence to achieve CIN3/carcinoma in situ lesions [28]. Also HPV-induced field effect is a risk factor for multicentric disease, as a persistent lesion allows continuous spreading of infective HPV [29].

\section{Head-neck}

The role of HPV in the pathogenesis of a subset of head and neck tumours, in particular in oropharyngeal squamous cell tumours (OPSCCs), has been well established [30, 31]. Patients with HPV-related cancers are more frequently younger and with a better prognosis than those with OPSCCs HPV-negative [31]. Numerous studies in the literature show an increased risk of SPCs onset after anogenital HPV-related lesion [6-8, 10, 23, 26]. We confirmed this evidence. (Table 4) compares the values of the literature with our study.

A Danish study shows that women with HPV-related OPSCC are more likely to be affected by cervical disease: the association between oral and cervical HPV related lesions is stronger for smoking patients than for nonsmokers [30]. Also sexual behaviours as unprotected oral

Table 4 Head and neck SPCs in CIN 2-3 LLETZ treated women. A comparison between literature and our study data

\begin{tabular}{lllll}
\hline Author & Year & First lesion & Value & Head and Neck \\
\hline Evans [26] & 2003 & CIN 3 & SIR & 1.2 \\
Kalliala [6] & 2005 & CIN 1-3 & SIR & 1.7 \\
Gaudet [10] & 2014 & CIN 2 & SIR & 0.47 \\
& & CIN 3 & SIR & 0.67 \\
Ebisch [8] & 2017 & CIN 3 & IRR & 5.51 \\
Suk [23] & 2018 & SCC & SIR & 1.4 \\
Wang [16] & 2020 & SCC & SIR & 2.29 \\
Our study & & CIN 2-3 & SIR & 8.5 \\
\hline
\end{tabular}

Legenda:

CIN Cervical Intraepithelial Neoplasia

IRR Incidence Rate Ratio

LLETZ Large Loop Excision of the Transformation Zone

SCC Invasive Squamous Cell Carcinoma

SIR Standardized Incidence Ratio sex and number of lifetime partners are considered risk factors. With the exception of HPV16, the HPV types that infect the cervix are different from those of oral area, and carcinogenesis mechanisms are not identical, even not yet fully understood [31]. OPSCC arise in a different epithelium from the cervical one without transformation zone, and no preinvasive oral lesion can be identified up to date. HPV genome integration occurs with different patterns: in cervical cancer through the classic E2 breakpoint, while in OPSCC throughout the entire genome, more frequently in E1 [31].

Unfortunately, we could not perform stratification to smoking habit because this information was not systematically recorded in our database.

\section{Lung and bladder}

There is recent hypothesis about the role of HPV in these cancers [32]. The most plausible cause of correlation between cervical and lung or bladder cancers is the common risk factor of smoking [32-34].

It has been hypothesized an association between bladder cancer and HPV. Anatomical proximity could be a potential cause for viral migration, since in women urethra is close to anogenital area which could be a reservoir for HPV. Also natural HPV tropism for squamous epithelium could facilitate infection [35].

As for lung, there is a variable reported incidence of HPV DNA in lung cancer specimens and it has been speculated that HPV reaches the lungs via the bloodstream, even if it is known that HPV does not cause generalized viremia [36]. It has been also proposed that HPV particles may be carried though air, raising the potential issue of occupational exposure for healthcare providers and exposure for patients during LLETZ procedures [37].

In our series all SPCs occurred after a CIN3 history, whereas in the lungs a greater heterogeneity of results was found: $9.8 \%$ after CIN1 history, 35.7\% after CIN2 and $35.7 \%$ after CIN3. While $25 \%$ of bladder lesions occur after CIN2 history and 75\% after treatment for CIN 3.

\section{Other Gynaecological sites}

Some studies aimed to find a biologically and clinically plausible explanation for breast or ovarian tumour occurrences in patients with a history of HPV-related lesions. Despite these studies, the scientific evidences of HPV involvement in breast carcinogenesis is not sufficient yet $[38,39]$. In breast and ovary numerous tumour occurrences have been found. We thought that this increased risk could depend on increased diagnostic attention and adherence to organized and spontaneous screening programs. 
The role of hormones in tumorigenesis in breast, ovary and thyroid cancers is to be considered as a possible common risk factor.

\section{Conclusions}

Cervical cancer screening program in Italy is constantly updated by GISCI, Italian Cervicocarcinoma Screening Group (www.gisci.it). Due to the low incidence of anal cancer (1-3 cases/100,000 women-years), vaginal cancer (0.5-1.7 cases/100,000 women-years) and vulvar cancer (1-to 4.6 cases/100,000 women-years) there are no costeffective screening programs for these tumours [40-43].

As invasive tumour lesions in these sites are preceded by pre-tumoral lesions and non-invasive diagnostic examinations are available, it could be appropriate to consider women treated for CIN3, as at greater risk of other HPV-related cancers, to be target of screening strategies.

To plan appropriate program for cervical precancer and cancer detection it should be suggested to continue screening after the age that usually negative women stop (65 years in Italy), as risk continues to be elevated even after 20 years from first treatment [7].

This prolongation or even a lifelong cervical cancer screening will allow detection of vaginal, vulvar and anal precancerous lesions too. For vaginal cancer, the personalized follow-up program would benefit from the high sensitivity of validated HPV tests combined with the high specificity of the cytology and colposcopy. Vulvar preinvasive lesions could also be detected during routine examination before the insertion of vaginal speculum to perform HPV or PAP test, through the correct and conscious inspection of the external genitalia. Thus it is of paramount importance to train healthcare providers (general practitioners, gynecologists and midwives) to a general assessment of genitalia.

In anal region, screening in CIN3 treated patients could use a threefold approach: cytology, high-resolution anoscopy and guided biopsy as the best resource currently available [44]. However there are no validated approaches to anal cancer screening due to its low incidence and the best option is limiting screening to highest risk subgroup, such as immunodepressed women (either from HIV or iatrogenic immunosuppression), women with multiple sexual partners, heavy smokers and with history of anal warts [45].

Despite the high specificity (92\%) and moderate sensitivity $(72 \%)$ of oral HPV detection methods [oral rinsing and oral swabs], even for head and neck cancers the opportunity of a screening program is affected by the low incidence in the general population of the same, especially in women. Moreover, unlike tumours in the anogenital area, there is no pre-tumour lesion that anticipates oral and oropharyngeal cancers, this further compromises the usefulness of a screening strategy $[30,46]$.
It remains to assess the impact of adjuvant HPV vaccination in treated patients: it has already demonstrated a protective effect in reducing recurrent intraepithelial cervical lesion but further studies are needed to evaluate the impact on HPV-related SPCs [47].

There are some limitations in our study. First the type of treatment of cervical lesions, LLETZ, could have influenced the study outcome, since it removes less tissue than cold knife conization. If this approach is of utmost clinical benefit for reduction of adverse obstetrics outcomes, it can leave in situ more HPV infected tissue. Also positive margin status and glandular involvement from a less invasive treatment could have influenced, as a result of incomplete excision or a lesion hidden in the glandular crypts. Secondly, our database is not representative of the entire Italian population but based on a regional cancer registry. Furthermore, we assumed that SPCs can be attributable to HPV infection persistence but HPV testing was not available in our retrospective database.

The increased risk of cancer in extra-cervical sites after CIN 2-3 treatment makes appropriate to introduce personalized follow-up and screening programs, while HPV vaccination needs further studies to assess its impact. The best strategy should be defined according to the economic budget of public health and to the workload of the hospital units in charge of their implementation.

\section{Abbreviations}

CIN: Cervical Intraepithelial Neoplasia; HPV: Human Papillomavirus; LLETZ: Large Loop Excision of the Transformation Zone; SIR: Standardized Incidence Ratio; SCP: Second Primary Cancer; RTP: Registro Tumori Piemonte, Piedmont Cancer Registry; OPSCC: Oropharyngeal Squamous Cell Tumours; RR: Relative Risk

\section{Acknowledgements}

Not applicable.

\section{Authors' contributions}

Study concepts: MP. Study design: SR, MP, LG. Data acquisition: CL, NG, FB. Quality control of data and algorithms: SR, CL, SC. Statistical analysis: SR, IS, PB. Manuscript preparation: MP, SR, CL. Manuscript editing: SR, MP, CL. Manuscript review: MP, SR, LM, NG, IS, SC, FB, PB, LG, CB. All authors read and approved the final manuscript.

\section{Funding}

This research did not receive any specific grant from funding agencies in the public, commercial, or not-for-profit sectors.

\section{Availability of data and materials}

The datasets used and/or analyzed during the current study are available from the corresponding author on reasonable request.

\section{Ethics approval and consent to participate}

This study has been approved by the istitutional review board (IRB) of the Department of Surgical Sciences University of Torino, Italy and written consent was obtained from each participant according to Declaration of Helsinki. Researchers conducted the study using newly assigned identification number and personal information was removed.

Consent for publication

Not applicable. 


\section{Competing interests}

The authors declare that they have no competing interests.

\section{Author details}

'Department of Surgical Sciences University of Torino, Via Ventimiglia 3, 10126 Torino, Italy. ${ }^{2}$ Piedmont Cancer Registry - CPO, Torino, Italy. ${ }^{3}$ Cancer Prevention Center of Piedmont, Torino, Italy.

Received: 13 February 2020 Accepted: 22 September 2020 Published online: 07 October 2020

\section{References}

1. Schiffman M, Castle PE, Jeronimo J, Rodriguez AC, Wacholder S. Human papillomavirus and cervical cancer. Lancet (London, England). 2007;370:890907. https://doi.org/10.1016/S0140-6736(07)61416-0.

2. Tommasino $M$. The human papillomavirus family and its role in carcinogenesis. Semin Cancer Biol. 2014;26:13-21. https://doi.org/10.1016/j. semcancer.2013.11.002.

3. De Sanjosé S, Brotons M, Pavón MA. The natural history of human papillomavirus infection. Best Pract Res Clin Obstet Gynaecol. 2018;47:2-13. https://doi.org/10.1016/j.bpobgyn.2017.08.015.

4. Doorbar J. Host control of human papillomavirus infection and disease. Best Pract Res Clin Obstet Gynaecol. 2018;47:27-41. https://doi.org/10.1016/j. bpobgyn.2017.08.001.

5. Serrano B, Brotons M, Bosch FX, Bruni L. Epidemiology and burden of HPVrelated disease. Best Pract Res Clin Obstet Gynaecol. 2018;47:14-26. https:// doi.org/10.1016/j.bpobgyn.2017.08.006.

6. Kalliala I, Anttila A, Pukkala E, Nieminen P. Risk of cervical and other cancers after treatment of cervical intraepithelial Neoplasia: retrospective cohort study. BMJ. 2005;331:1183-5. https://doi.org/10.1136/bmj.38663.459039.7C.

7. Kalliala I, Athanasiou A, Veroniki AA, Salanti G, Efthimiou O, Raftis N, Bowden S, Paraskevaidi M, Aro K, Arbyn M, Bennett P, Nieminen P, Paraskevaidis E, Kyrgiou M. Incidence and mortality from cervical cancer and other malignancies after treatment of cervical intraepithelial neoplasia: a systematic review and meta-analysis of the literature. Ann Oncol. 2020;31: 213-27.

8. Ebisch RMF, Rutten DWE, IntHout J, Melchers WJG, Massuger LFAG, Bulten J, et al. Long-lasting increased risk of human papillomavirus-related carcinomas and Premalignancies after cervical intraepithelial Neoplasia grade 3: a population-based cohort study. J Clin Oncol. 2017;35:2542-50. https://doi.org/10.1200/JCO.2016.71.4543.

9. Edgren $G$, Sparén P. Risk of anogenital cancer after diagnosis of cervical intraepithelial neoplasia: a prospective population-based study. Lancet Oncol. 2007:8:311-6. https://doi.org/10.1016/S1470-2045(07)70043-8.

10. Gaudet M, Hamm J, Aquino-Parsons C. Incidence of ano-genital and head and neck malignancies in women with a previous diagnosis of cervical intraepithelial neoplasia. Gynecol Oncol. 2014;134:523-6. https://doi.org/10. 1016/j.ygyno.2014.07.088

11. Sand FL, Munk C, Jensen SM, Svahn MF, Frederiksen K, Kjær SK. Long-term risk for noncervical anogenital cancer in women with previously diagnosed high-grade cervical intraepithelial neoplasia: a Danish nationwide cohort study. Cancer Epidemiol Biomark Prev. 2016;25:1090-7. https://doi.org/10. 1158/1055-9965.EPI-15-1291.

12. Saleem AM, Paulus JK, Shapter AP, Baxter NN, Roberts PL, Ricciardi R. Risk of anal cancer in a cohort with human papillomavirus-related gynecologic neoplasm. Obstet Gynecol. 2011;117:643-9. https://doi.org/10.1097/AOG. 0b013e31820bfb16.

13. Neumann F, Jégu J, Mougin C, Prétet JL, Guizard AV, Lapôtre-Ledoux B, et al. Risk of second primary cancer after a first potentially-human papillomavirus-related cancer: a population-based study. Prev Med (Baltim). 2016;90:52-8. https://doi.org/10.1016/j.ypmed.2016.06.041.

14. Acevedo-Fontánez Al, Suárez E, Torres Cintrón CR, Ortiz AP. Risk of anal Cancer in women with a human papillomavirus-related gynecological neoplasm: Puerto Rico 1987-2013. J Low Genit Tract Dis. 2018:22:225-30. https://doi.org/10.1097/LGT.0000000000000395.

15. Viarisio D, Gissmann L, Tommasino M. Human papillomaviruses and carcinogenesis: well-established and novel models. Curr Opin Virol. 2017;26: 56-62. https://doi.org/10.1016/J.COVIRO.2017.07.014.

16. Wang M, Sharma A, Osazuwa-peters N, Simpson MC, Schootman M, Piccirillo JF, et al. Risk of subsequent malignant neoplasms after an index potentially-human papillomavirus ( HPV) -associated cancers. Cancer
Epidemiol. 2020;64(Augus2019):101649. https://doi.org/10.1016/j.canep.2019. 101649

17. Testori A, Cioffi U, De Simone M, Bini F, Vaghi A, Lemos AA, et al. Multiple primary synchronous malignant tumors. BMC Res Notes. 2015;8:1-4. https:// doi.org/10.1186/s13104-015-1724-5.

18. Pandey NO, Chauhan AV, Raithatha NS, Patel PK, Khandelwal R, Desai AN, Choxi Y, Kapadia RS, Jain ND. Association of TLR4 and TLR9 polymorphisms and haplotypes with cervical cancer susceptibility. Sci Rep. 2019;9.

19. Organization WHO, international agency for research on cancer humans ocrt. Monographs on the Evaluation of Carcinogenic Risks to Humans Human Papillomaviruses. Vol. 90, International Agency for Research on Cancer larc; 2007. p. 33-43.

20. Luhn P, Walker J, Schiffman M, Zuna RE, Dunn ST, Gold MA, Smith K, Mathews C, Allen RA, Zhang R, Wang S, Wentzensen N. The role of cofactors in the progression from human papillomavirus infection to cervical cancer. Gynecol Oncol. 2013;128(2):265-70. https://doi.org/10.1016/j.ygyno. 2012.11.003.

21. Mantel N, Haenszel MW. Statistical aspects of thee analysis of data from retrospective studies of disease. J Nat Cancer Inst. 1959;22:719-48.

22. Strander B, Andersson-Ellstrom A, Milsom I, Sparen P. Long term risk of invasive cancer after treatment for cervical intraepithelial neoplasia grade 3 : population based cohort study. Bmj. 2007;335:1077. https:/doi.org/10.1136/ bmj.39363.471806.BE.

23. Suk R, Mahale P, Sonawane K, Sikora AG, Chhatwal J, Schmeler KM, Sigel K, Cantor S, Chiao EY, Deshmukh A. Trends in risks for second primary cancers associated with index human papillomavirus-associated cancers. JAMA Netw Open. 2018;1:e181999. https://doi.org/10.1001/jamanetworkopen.2018.1999.

24. Balasubramaniam SD, Balakrishnan V, Ein Oon C, Kau G. Key molecular events in cervical Cancer development. Medicina. 2019;55:384. https://doi. org/10.3390/medicina55070384.

25. Bertoli HK, Thomsen LT, Iftner T, Dehlendorff C, Kjær SK. Risk of vulvar, vaginal and anal high-grade intraepithelial Neoplasia and Cancer according to cervical human papillomavirus (HPV) status: a population-based prospective cohort study. Gynecol Oncol. 2020;157:456-62. https://doi.org/ 10.1016/j.ygyno.2020.01.030.

26. Evans HS, Newnham A, Hodgson SV, Møller H. Second primary cancers after cervical intraepithelial neoplasia III and invasive cervical cancer in Southeast England. Gynecol Oncol. 2003;90:131-6. https://doi.org/10.1016/S00908258(03)00231-2.

27. Tatti S, Suzuki V, Fleider L, Maldonado V, Caruso R, Tinnirello MDLA. Anal intraepithelial lesions in women with human papillomavirus-related disease. J Low Genit Tract Dis. 2012;16:454-9. https://doi.org/10.1097/LGT. Ob013e31825d2d7a.

28. Carreon JD, Sherman ME, Guillén D, Solomon D, Herrero R, Jerónimo J, Wacholder S, et al. CIN2 is a much less reproducible and less valid diagnosis than CIN3: results from a histological review of population-based cervical samples. Int J Gynecol Pathol. 2007;27:441-6. https://doi.org/10.1097/pgp. 0b013e31805152ab.

29. Adams TS, Mbatani NH. Clinical Management of Women Presenting with field effect of HPV and intraepithelial disease. Best Practice \& Research Clinical Obstetrics \& Gynaecology. 2018;47:86-94. https://doi.org/10.1016/j. bpobgyn.2017.08.013.

30. Thomsen LT, Kjær SK. Women with cervical cancer precursor lesions: a highrisk group for human papillomavirus (HPV)-related oropharyngeal cancer? Acta Oncol (Madr). 2019;0:1-2. https://doi.org/10.1080/0284186X.2019. 1581378.

31. Pan C, Issaeva N, Yarbrough WG. HPV-driven oropharyngeal cancer: current knowledge of molecular biology and mechanisms of carcinogenesis. Cancers Head Neck. 2018;3:1-11. https://doi.org/10.1186/s41199-018-0039-3.

32. Peña N, Carrillo D, Muñoz JP, Chnaiderman J, Urzúa U, León O, et al. Tobacco smoke activates human papillomavirus 16 p97 promoter and cooperates with high-risk E6/E7 for oxidative DNA damage in lung cells. PLoS One. 2015;10:1-16. https://doi.org/10.1371/journal.pone.0123029.

33. Xiong WM, Xu QP, Li X, Xiao RD, Cai L, He F. The association between human papillomavirus infection and lung cancer: a system review and meta-analysis. Oncotarget. 2017;8:96419-32. https://doi.org/10.18632/ oncotarget.21682.

34. House R, Janakiraman $\mathrm{H}$, Ogretmen B, Kato M, Erkul E, et al. Smokinginduced control of miR-133a-3p alters the expression of EGFR and HuR in HPV-infected oropharyngeal cancer. 2018:1-17. https://doi.org/10.1371/ journal.pone.0205077. 
35. Egawa N, Egawa K, Griffin H, Doorbar J. Human papillomaviruses; epithelial tropisms, and the development of Neoplasia. Viruses. 2015;7:3863-90. https://doi.org/10.3390/v7072802.

36. Chiou HL, Wu MF, Liaw YC, Cheng YW, Wong RH, Chen CY, Lee H. The presence of human papillomavirus type 16/18 DNA in blood circulation may act as a risk marker of lung Cancer in Taiwan. Cancer. 2003;97:1558-63. https://doi.org/10.1002/cncr.11191.

37. Fox-Lewis A, Allum C, Vokes D, Roberts S. Human papillomavirus and surgical smoke: a systematic review. Occup Environ Med. 2020. https://doi. org/10.1136/oemed-2019-106333.

38. Araldi RP, Sant'Ana TA, Módolo DG, de Melo TC, Spadacci-Morena DD, de Cassia SR, et al. The human papillomavirus (HPV)-related cancer biology: an overview. Biomed Pharmacother. 2018;106:1537-56. https://doi.org/10.1016/ j.biopha.2018.06.149.

39. Balci FL, Uras C, Feldman SM. Is human papillomavirus associated with breast cancer or papilloma presenting with pathologic nipple discharge? Cancer Treat Res Commun. 2019;19. https://doi.org/10.1016/j.ctarc.2019. 100122.

40. Cromwell I, Gaudet M, Peacock SJ, Aquino-Parsons C. Cost-effectiveness analysis of anal cancer screening in women with cervical neoplasia in British Columbia, Canada. BMC Health Serv Res. 2016;16:1-10. https://doi.org/10. 1186/s12913-016-1442-2.

41. Darragh TM, Winkler B. Anal cancer and cervical cancer screening: key differences. Cancer Cytopathol. 2011;119:5-19. https://doi.org/10.1002/cncy. 20126.

42. Slama J, Sehenal B, Dusek L, Zima T, Cibula D. Impact of risk factors on prevalence of anal HPV infection in women with simultaneous cervical lesion. Neoplasma. 2015;62:2. https://doi.org/10.4149/neo.

43. Ehrenpreis ED, Smith DG. Patients with newly diagnosed cervical cancer should be screened for anal human papilloma virus and anal dysplasia: results of a pilot study using a STELLA computer simulation and economic model. Papillomavirus Res. 2018;5:38-45. https://doi.org/10.1016/j.pvr.2017. 12.001.

44. Wells J, Flowers L, Sudeshna P, Minh LN, Anjali S, Marcia H. Knowledge of Anal Cancer, Anal Cancer Screening, and HPV in HIV-Positive and High-Risk HIV-Negative Women. J Cancer Educ. 2019. https://doi.org/10.1007/s13187019-01503-8.

45. Ramos-Cartagena JM, Pérez CM, Guiot HM, Amaya-Ardilla CP, Tirado-Gómez M, Ortiz AP. Assessment of Anal Cancer Screening Tools in Detecting HighGrade Anal Squamous Intraepithelial Lesions in Women. J Low Genit Tract Dis 2020 Jan;24(1):75-81. doi: 10.1097/LGT.0000000000000497.

46. Beaglehole R, Bonita R, Kjellström T. Epidemiologia di base. 1997;15-36:6582.

47. Lichter K, Krause D, Xu J, Tsai SHL, Hage C, Weston E, Eke A, Levinson K. Adjuvant human papillomavirus vaccine to reduce recurrent cervical dysplasia in unvaccinated women: a systematic review and meta-analysis. Obstet Gynecol. 2020 May;135(5):1070-83. https://doi.org/10.1097/AOG. 0000000000003833 .

\section{Publisher's Note}

Springer Nature remains neutral with regard to jurisdictional claims in published maps and institutional affiliations.

Ready to submit your research? Choose BMC and benefit from:

- fast, convenient online submission

- thorough peer review by experienced researchers in your field

- rapid publication on acceptance

- support for research data, including large and complex data types

- gold Open Access which fosters wider collaboration and increased citations

- maximum visibility for your research: over $100 \mathrm{M}$ website views per year

At $\mathrm{BMC}$, research is always in progress.

Learn more biomedcentral.com/submissions 